\title{
ПОРІВНЯЛЬНО-МОРФОЛОГІЧНИЙ АНАЛІЗ БУДОВИ ЯЙЦЕКЛАДІВ, СПЕРМАТЕК ТА ЛИЧИНОК 1-ГО ВІКУ САМОК ТАХІН ДЕЯКИХ ВИДІВ ТРИБИ VORIINI (DIPTERA, TACHINIDAE)
}

\author{
Фаринець C.I.
}

\begin{abstract}
Порівняльно-морфологічний аналіз будови яйцекладів, сперматек та личинок 1-го віку самок тахін деяких видів триби Voriini (Diptera, Tachinidae).- C.I. Фаринець. - В роботі наведені результати вивчення морфології генітальних структур самок мух-тахін триби Vогіini. Проаналізовано показники 18 ознак постабдомена, сперматек та личинок 1-го віку. Отримані дані дозволяють більш аргументовано трактувати диференціацію таксонів родового рівня та їх філогенію. Вивчення окремих структур статевої системи самок $і$ личинок 1-го віку Vогіini дозволяє виявити адаптивні процеси розвитку постабдомена самок, щзо пов'язано зі способом зараження хазяїна, та виявити напрямок еволюиійних перетворень иџих структур. За особливостями структури геніталій самок представники триби Vогіiпі виявилися досить різноманітними. 3 одного боку Vогіiпі подібні за окремими структурами геніталій з Dехііпі: повна редукиія кінцевого тергіта, редукція VIII та збереження у більшості иілих VI, VII, іноді VIII тергітів, редукція волосків на поверхні VIII стерніта і виникнення на ньому сенсорних пор. Також у деяких представників Voriini (Eriothrix, Peteina, Thelaira, Stomina) канали сперматек, подібно до Dехііпі. з'єднані $з$ вагіною одним загальним коротким протоком. Серед иьього угруповання виділяються Егіотhrix будовою капсул сперматек та Stomina повною редукиією VIII, кінцевого тергітів і VIII стерніта. На наш погляд, зв'язок каналів сперматек з вагіною не зазнає адаптивних змін $і$ відображає зв'язки таксонів високого рангу. Таким чином, морфологічні особливості генітальних структур самок, личинки 1-го віку правомірно використовувати поряд $з$ морфологічними ознаками імаго при з'ясуванні родинних відносин, видових і родових відмінностей, а також при вивченні філогенії. На основі проаналізованих 22 морфологічних ознак сперматек $і$ яйцекладів складено ключі для визначення 12 видів мух-тахін триби Voriini.
\end{abstract}

Ключові слова: мухи-тахіни, морфологія, постабдомен, яйцеклад, сперматека, личинки, таблиці для визначення. Адреса: ДВНЗ «Ужгородський начіональний університет», біологічний факультет, кафедра зоології, вул. Волошина, 32, Ужгород, 88000 Украӥна; e-mail: stepan.farinets@uzhnu.edu.иа

Comparative-morphological analysis of structure of oviposition, spermathek and larvae of $1^{\text {st }}$ age of females of some Voriini tribe species (Diptera, Tachinidae). - S.I. Farynets. - The results of study of morphology of genital structures of tachinids' flies of Voriini tribes are presented in a paper. Indication of 18 signs of postabdomen, spermathecae, and larvae of the $1^{\text {st }}$ age are analyzed. The obtained data allow more reasonably to interpret a differentiation of taxa of generic level and their phylogeny. The study of the structures of females' sex system and larvae of the $1^{\text {st }}$ age allows to identify adaptive processes of evolutionary development of females postabdomen that is related to a way of infection of hosts, and to reveal a direction of evolutionary transformations of these structures. According to structural features of the genital structure of females of Voriini tribe proved to be quite diverse. Some genital structures of Voriini is a similar to Dexiini tribe: complete reduction of terminal tergite; reduction VIII and the presence of the whole VI, VII, and sometimes VIII tergites; reduction of chaetae on the surface of VIII sternite, and appearance of sensory pores on it. Channels of spermathecae of some Voriini representatives (Eriothrix, Peteina, Thelaira, Stomina genera) are connected with vagina by one general short duct like Dexiini species, also. Among these groups Eriothrix is divided by the structure of capsules of the spermathecae, and Stomina by complete reduction of VIII and terminal tergites, and VIII sternite. A connection of the channels of spermathecae with vagina does not undergo adaptive changes and reflects the connections of high-ranking taxa. Thus, the morphological features of the genital structures of femalesand larvae of the $1^{\text {st }}$ age can be used lawfully with the morphological features of the imago in a clarification of family relationships, species and genera differences, as well as in the study of phylogeny. Identification keys for 12 species of tachinids of Voriini tribe were made on the basis of the analyzed 22 morphological characteristics of spermathecae and ovipositors.

Keywords:tachinids, morphology, postabdomen, ovipositor, spermatheca, larvae, identification keys. 
Address: Uzhhorod National University, Faculty of Biology, Department of Zoology, 32, Voloshyna str., Uzhhorod, 88000 Ukraine; e-mail: stepan.farinets@uzhnu.edu.ua

\section{Вступ}

Більшість таксономічних робіт не торкаються або лише поверхово розглядають морфологічні структури геніталій самок тахін, вони мало відомі i не часто розглядаються в оглядових роботах. Крім того, відсутні узагальнюючі порівняльноморфологічні роботи, в яких були б детально вивчені личинки 1-го віку, різноманітність сперматек та постабдоменів самок.

Відомо декілька робіт 3 вивчення екзоскелету постабдоменів самок тахін (Herting 1960; Hori 1966; Tachi, Shima 2000; Farynets 1996, 1997, 2002); сперматек (Herting 1960; Hori 1966; Farynets 2003, 2008); личинок1-го віку (Thompson 1923, 1926; Tachi, Shima 2000; Viktorov 1967; Farynets 1976a,b; Rikhter, Farynets 1979, 1983, 1986, 1989; Khitsova et al. 1977).

За даними Х.-П. Чорсніга і Б. Хертінга (Tschorsnig, Herting 1994), личинки Eriothrix Meigen, 1803. паразитують в гусеницях Pyralidae; Blepharomyia Brauer \& Berganstamm, 1889 - в гусеницях Geometridae, Noctuidae; родів Ramonda Robineau-Desvoidy 1863; Periscepsia Gistel 1848; Athrycia Robineau-Desvoidy 1830; Voria RobineauDesvoidy 1830; Peteina Meigen 1838 - в гусеницях Noctuidae; Pyllomyia Robineau-Desvoidy 1830 - в личинках Tenthredinidae; Thelaira RobineauDesvoidy 1830 - в гусеницях Arctiidae; для роду Stomina Robineau-Desvoidy 1830 хазяї невідомі.

Вивчення окремих структур статевої системи самок і личинок 1-го віку Voriini дозволяє виявити адаптивні процеси розвитку постабдомена самок, що пов'язано зі способом зараження хазяїна та виявити напрямок еволюційних перетворень цих структур. Ціль нашої роботи $є$ вивчення генітальних структур самок деяких видів триби Voriini та личинок 1-го віку 3 метою оцінки можливості використання цих ознак в таксономії.

\section{Матеріал та методи дослідження}

Матеріал для роботи був зібраний на території Українських Карпат (Farynets 1976c,d, 1977, 2000). Триба Voriini в Палеарктиці нараховує 33 роди (Herting 1984). 3 цієї кількості нами вивчені личинки 1-го віку 5 родів, та деяких видів яйцеклади і сперматеки 10 родів.

Яйцеклад відпрепаровували шляхом легкого натискання на черевце самки і його відокремлення. Для вивчення постабдоменів самок у сухих екземплярів їx перед відділенням черевця розмочували у вологій камері. Відокремлену задню частину черевця виварювали у розчині гідроксиду калію, промивали і виготовляли препарат. Відокремлений постабдомен після вивчення зберігали у целулоїдній лунці в краплі гліцерину.

Загальний план будови сперматек, постабдомена самок та личинок 1-го віку. Основним компонентом генітальних органів самок $є$ парні яєчники, які складаються з щільно з'єднаних оваріол, матки, сім'яприймачів, придаткових залоз, постабдомена. Зовнішній вигляд окремих представників Voriini та загальний план будови статевої системи самки тахін ілюструють рисунки (рис.1: a-h;3). Зрілі яйця через парні яйцепроводи попадають у вагіну - непарний трубчастий орган. У тахін, які відкладають невелику кількість яєць, вагіна не розширена, проте у видів, які відкладають багато яєць спостерігається, збільшення іiі довжини і товщини. Особливе збільшення матки відбувається у самок таких видів, в яких заплідненні яйця залишаються у вагіні до моменту розвитку в них личинок. Внаслідок цього матка розширюється, видовжується і закручується у спіраль, повністю заповнюючи черевце самки. Численні трахеї, які оплітають матку у крупних видів тахін, доставляють кисень для розвитку зародка.

На початку вагіни відкриваються протоки сім'яприймачів, яких у більшості тахін три, іноді лише два (Actia R-D., Peribaea R-D., Siphona Mg.) (Farynets2008). Протока одного $з$ сім'яприймачів впадає у вагіну попереду двох інших. Кожна 3 трьох проток сперматек самки впадає у вагіну своїм окремим протоком. Проте у окремих Voriini протоки сперматек впадають у вагіну самостійно (рис. 2: c,e-і) або в складі однієї короткої протоки, яка їх з'єднує з вагіною (рис.2: a, b, d,j,k).

Сперматеки складаються 3 овальної, грушоподібної або округлої капсули, які заповнені спермою. Стінки сперматек з середини сильно хітинізовані, зовні, як і протоки сперматек, вкриті залозистим епітелієм (рис. 3:В). Під капсулою знаходиться канал сперматеки, який на початку тонкий, у деяких тахін з потовщенням комірцем. У більшості тахін по середині довжини каналу знаходиться розширення каналу, який далі знову стає тонким, як і на його початку. 


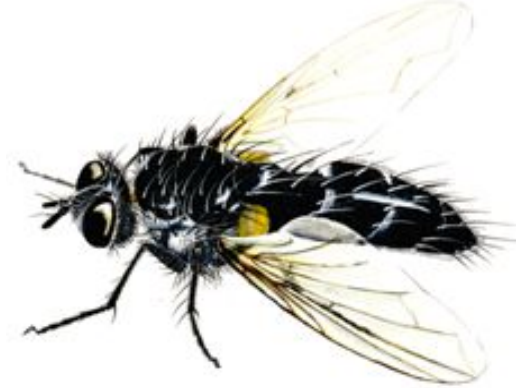

a

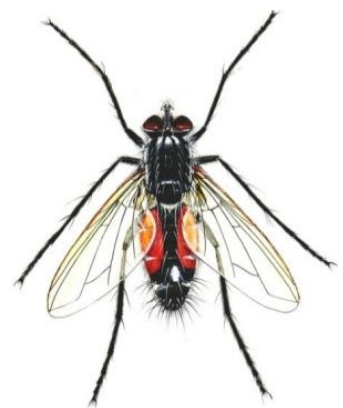

c

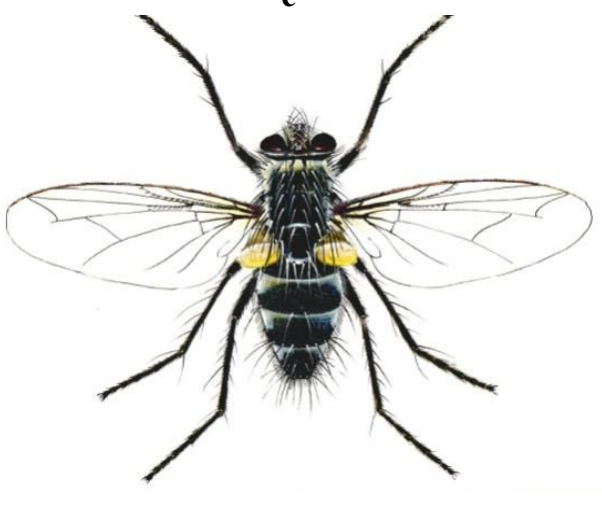

e

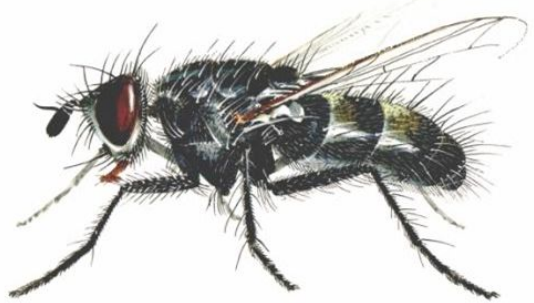

g

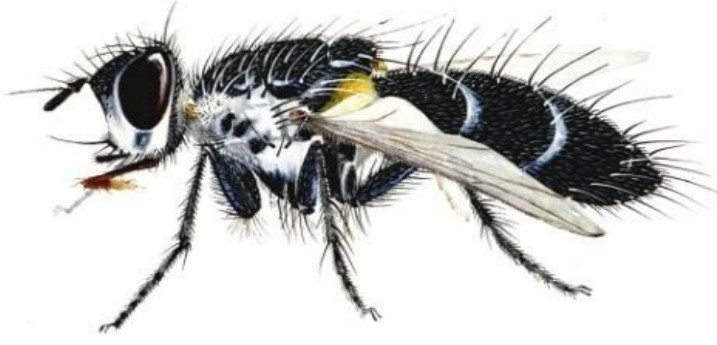

b

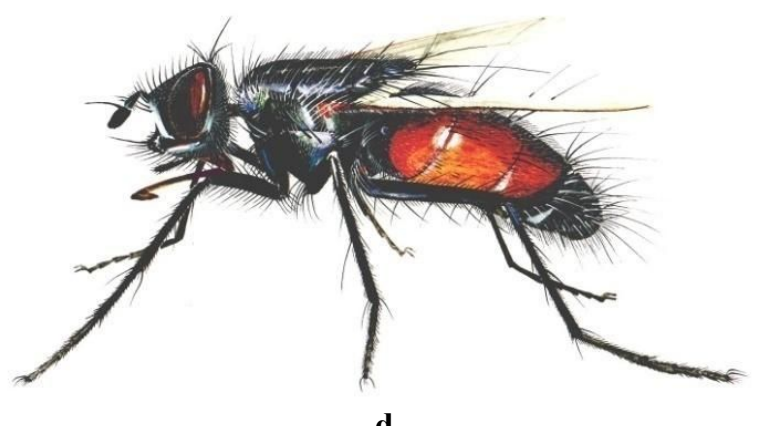

d
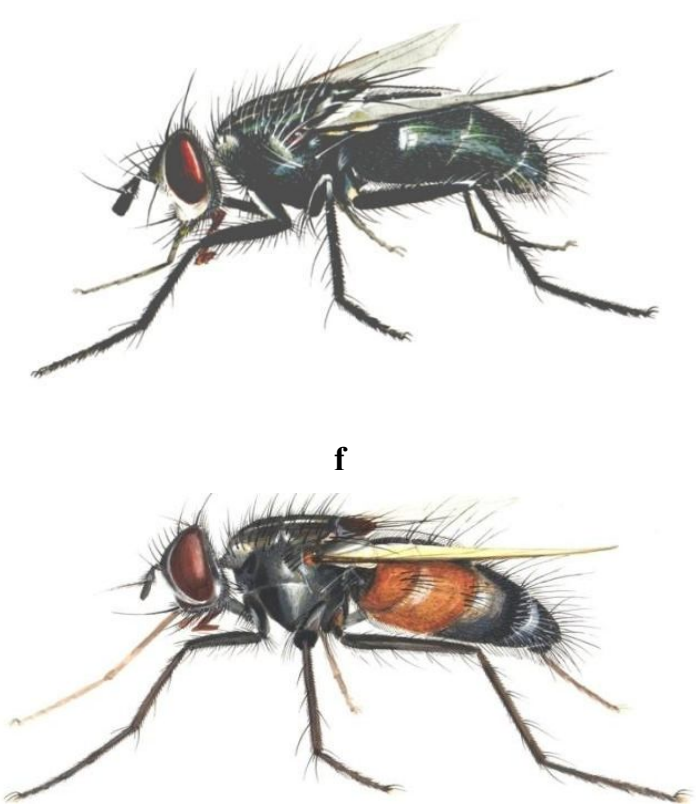

h

Рис. 1. Габітус самок окремих представників триби Voriini: a - Phyllomya volvulus (Fabricius), вигляд зверху; b - Phyllomya volvulus, вигляд збоку;с - Eriothrix rufomaculatus (De Geer), вигляд зверху; d Eriothrix rufomaculatus, вигляд збоку; е - Voria ruralis (Fallen), вигляд зверху;f - Voria ruralis, вигляд збоку; g - Athrycia trepida (Meigen), вигляд збоку; $\mathrm{h}$ - Thelaira nigripes (Fabricius), вигляд збоку

Fig. 1. Females habitus of some representatives of Voriini tribe: a - Phyllomya volvulus (Fabricius), top; $\mathrm{b}-$ Phyllomya volvulus, lateral; c - Eriothrix rufomaculatus (DeGeer), top; d - Eriothrix rufomaculatus, lateral; eVoria ruralis (Fallen), top; $\mathrm{f}$ - Voria ruralis, lateral; $\mathrm{g}$ - Athrycia trepida (Meigen), lateral; $\mathrm{h}$ - Thelaira nigripes (Fabricius), lateral 


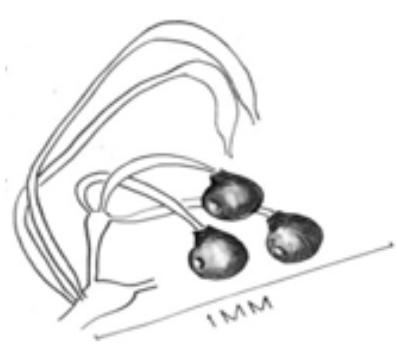

a

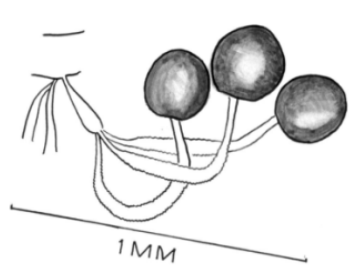

d

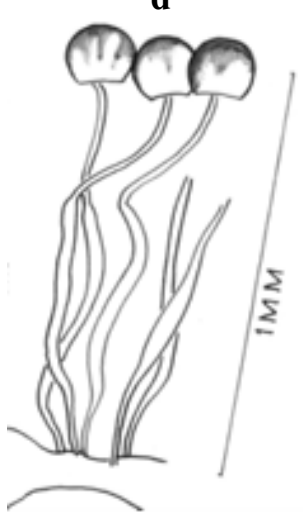

g

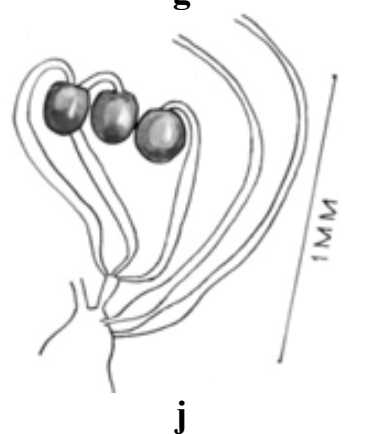

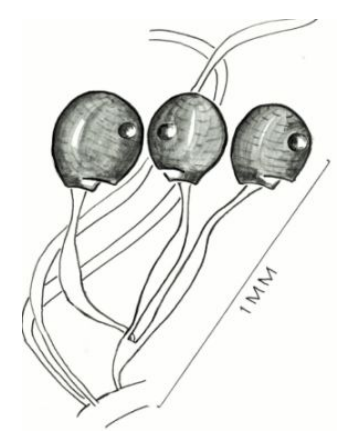

b

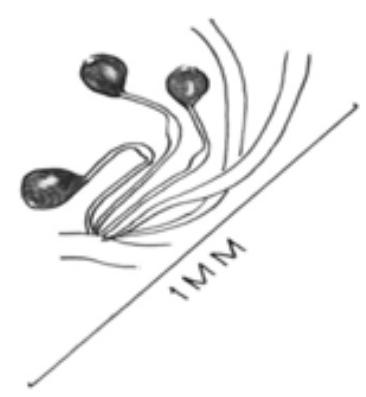

e

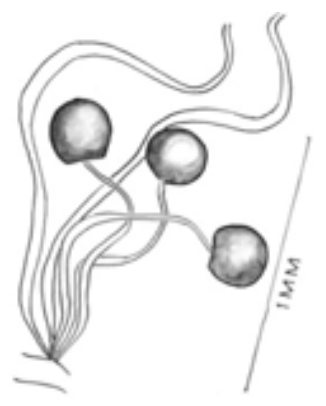

h

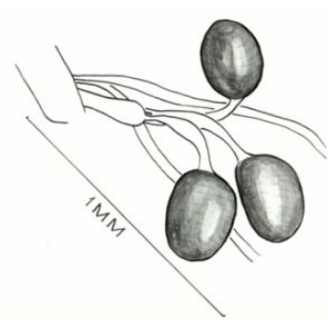

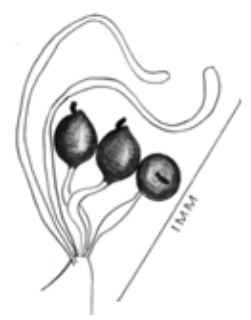

c

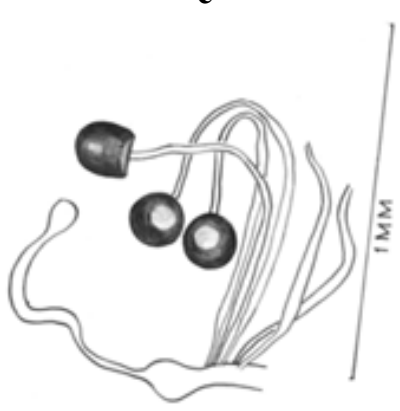

f

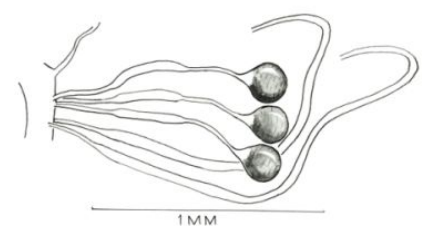

i

k

Рис. 2. Будова сперматек: a - Eriothrix rufomaculatus (De Geer); b - Eriothrix apenninus (Rondani); c Blepharomyia pagana (Meigen); d - Petina erinaceus Fabricius; e - Periscepsia carbonaria (Panzer); f Ramonda spathulata (Fallen); g - Athricia trepida (Meigen); $\mathrm{h}$ - Voria ruralis (Fallen); i-Phyllomya volvulus (Fabricius); $\mathrm{j}$ - Thelaira nigripes (Fabricius); $\mathrm{k}$ - Stomina caliendrata (Rondani)

Fig. 2. Structure of spermatheca: a - Eriothrix rufomaculatus (De Geer); b - Eriothrix apenninus (Rondani); c Blepharomyia pagana (Meigen); d - Petina erinaceus Fabricius; e - Periscepsia carbonaria (Panzer); f Ramonda spathulata (Fallen); g - Athricia trepida (Meigen); h - Voria ruralis (Fallen); i - Phyllomya volvulus (Fabricius); $\mathrm{j}$ - Thelaira nigripes (Fabricius); $\mathrm{k}$ - Stomina caliendrata (Rondani) 

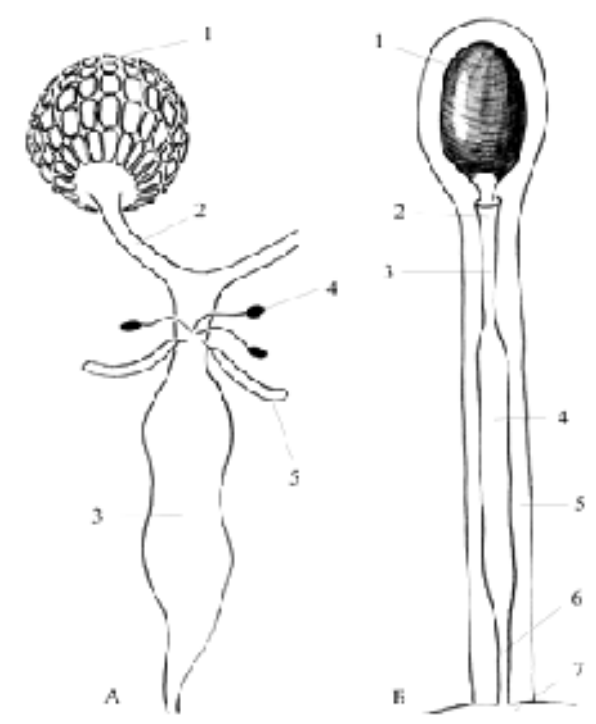

Рис. 3. Схема будови статевої системи самок тахін: А - загальний план будови (1- яєчник, 2- яйцепровід, 3 - вагіна, 4 - сперматеки, 5 - придаткові залози); Б - будова сперматеки (1 - склеротизована капсула сім'яприймача, 2 - комірець канала, 3 - початок канала сперматек, 4 - середнє розширення каналу, 5 залозистий покрив, 6 - кінець каналу сперматеки, 7 - вагіна)

Fig. 3. Scheme of structure of tachins' females sex system: A - general plan of the structure (1 - ovary, 2 oviduct, 3 - vagina, 4 - spermatheca, 5 - adnexal glands); B - structure of the spermatheca (1 - sclerotic capsule of the spermatheca, 2 - collar of canal, 3 - beginning of the spermatheca channel, 4 - medium duct enlargement, 5 - glandular covering, 6 - end of the spermatic duct, 7 - vagina)

Позаду протоків сперматек у вагіну впадає пара придаткових залоз, які, на думку I. Белановського (1951) виділяють липку рідину, за допомогою якої приклеюються яйця до субстрату. Б. Хертінг (Herting 1960) трактує, що функція цих залоз невідома. У всіх тахін придаткові залози впадають у вагіну тонкими протоками, які у деяких груп різні за довжиною, інша частина залоз більш або менш потовщена (рис. 3:А).

Будова личинок 1-го віку тахін наведена у роботах С. Фаринця із співавторами (Farynets 1976a,b; Rikhter, Farynets 1979, 1983, 1986, 1989).

Сегменти черевця, починаючи з VI, які беруть участь в утворені генітальних структур, називаються генітальними. До їх складу входять VI-XI сегменти черевця, які у більшості тахін рухомо з'єднані і в спокійному стані втягнуті. Часто ці сегменти називають постабдомінальними, термінальними або яйцекладом. Сегменти черевця складаються із двох пластинок (склеритів): спинної - тергіта і черевної стерніта, які з'єднані мембраною. На VI і VII сегментах розміщені дихальця. У родинно близьких до тахін деяких двокрилих, зокрема, саркофагів, так само як і у тахін, розміщення дихалець VII сегмента зміщені на VI сегмент, що деякі дослідники зв'язують з редукцією VII терміта (Herting 1954). Однак, існують прихильники іншої думки (Kulikova 1980; Lobanov 1977), які стверджують, що парні дихальця на VI сегменті у деяких двокрилих виникли внаслідок злиття VI і VII сегментів. IX i $\mathrm{X}$ тергіти злиті, утворюючи кінцевий тергіт. На вершині яйцеклада знаходяться одночленикові церки.

Вентральні склерити постабдомена представлені відповідно VI, VII, VIII стернітами. Постгенітальна пластинка утворена у результаті злиття IX i $\mathrm{X}$ стернітів. До IX стерніта відносяться передньолатеральні вирости постгенітальної пластинки, які загнуті вентрально і назад - лінгули (Herting 1960), або аподема (Rodendorf 1937).

\section{Результати та обговорення}

У представників роду Eriothrix (рис. 2: a, b) капсули сперматек у профіль овальні, неправильно кулеподібні, сильно пігментовані, 3 слабо вираженими поперечними смужками, у яких вершинне округле впинання зміщене на 
екваторіальну площину. Кожний канал сперматек у 2 рази довший за капсули сперматек. Протоки сперматек з'єднані з вагіною однією короткою протокою (рис. 2: а). Придаткові залози тонкі і довші за протоки і капсули сперматек разом.

Псевдоцефал личинок 3 дископодібними антенами (Farynets 1976a). I-III грудні та I черевний сегменти на передньому краї 3 дрібними шипами. II-VI черевні сегменти вентрально 3 шипами, їх дорзальна поверхня гола. VII черевний сегмент на задньому краї з 1-2 рядами шипів. Середнє вістря вентрально слабо випукле, на вершині звужене, його довжина менша за довжину гіпостомального відділу (рис. 4: а).

VI тергіт постабдомена може бути цілісним (E. Rufomaculata De Geer 1776, E. Prolixa Meigen 1824) (рис.5: c, d), дорзально поділеним на 2 однакові склеритиіз щетинками на задньому краї (E. Apennina Rondani 1862 (рис. 5: b). VII тергіт редукований, дорзально поділений на 2 склерити (E. rufomaculata, E. apennina), 3 щетинками на задньому краї або без щетинок, у E. prolixa він цілісний. Кінцевий та VIII тергіти повністю редуковані. VI-VIII стерніти різні за формою 3 довгими щетинками на задньому краї.

У представників роду Blepharomyia сперматеки овально-видовжені, на вершині звужені та 3 папілоподібним виростом. Сперматеки сильно склеротизовані 3 слабо помітними поперечними смужками. Протоки сперматек трохи довші за довжину капсул сперматек. Придаткові залози тонкі та довгі (рис. 2: с).

Псевдоцефал личинки 1-го віку з дрібними дископодібними сенсорними органами. I-III грудні і I-VI черевні сегменти на вентральній поверхні голі. I-III грудні сегменти на дорзальній поверхні голі. I-VII черевні сегменти на дорсальній поверхні з 2 групами шипів, які по середині сегмента розділенні вузьким проміжком голої кутикули. VII черевний сегмент на задньому краї з 4-5 неправильними рядами шипів, які направлені вперед. Задня половина VIII черевного сегмента покрита шипами, з яких задні більші за розміром і направлені вперед (рис. 4: b). Середнє вістря до вершини поступово звужується, зігнуте вентрально. Довжина середнього вістря майже в 3 рази більша його ширини. Гіпостомальний відділ коротший за середнє вістря. Бокові склерити видовжені слабо пігментовані (Farynets 1976a).
VI тергіт постабдомена цілісний 3 щетинками на задньому краї. VII тергіт по середині поділений на 2 однакові склерити 3 щетинками на задньому краї. VIII тергіт по середині поділений на 2 однакові дрібні без щетинок склерити, які зміщені на латеральну сторону. VI-VIII стерніти по середині на задньому краї звужені та $з$ дрібними щетинками (рис. 5: d).

У представників роду Peteina капсули сперматек майже округлої форми, без поперечних смужок. Кожний канал сперматек у 3 рази довші за капсули сперматек. Протоки сперматек впадають у вагіну в складі загальної короткої протоки, яка з'єднує їх 3 вагіною (рис. 2: d). Придаткові залози тонкі.

Личинки 1-го віку невідомі.

VI-VII тергіти постабдомена цілісні 3 щетинками на їх задньому краї. VIII тергіт по середині поділений на 2 однакові дрібні без щетинок склерити, які зміщені на латеральну сторону. Кінцевий тергіт повністю редукований. VI,VII стерніти на задньому краї з щетинками. Поверхня VIII стерніта повністю покрита дрібними щетинками, до заднього краю звужений (рис.5: е).

У представників роду Ramonda капсули сперматек майже округлої форми без поперечних смужок, але їх вегетативний полюс прямий. Кожний канал сперматек приблизно у 6 разів довший за капсули сперматек. Всі протоки сперматек окремо впадають у вагіну. Придаткові залози тонкі і довгі (рис.2: f).

Личинки 1-го віку (рис. 4: с) різні за будовою (Farynets 1976a; Rikhter, Farynets 1989). Псевдоцефал 3 дрібними дископодібними сенсорними органами, їх ширина більша за висоту. Грудні сегменти голі (Ramonda spathulata Fallén 1820) або 3 декількома рядами шипів (Ramonda prunicia Herting 1969). I-VII черевні сегменти голі (Ramonda spathulata) або з шипами по передньому краї на вентральній і дорзальній поверхі (Ramonda prunicia). VIII черевний сегмент на передньому краї $з$ пояском сильно пігментованих густих шипів різної форми (Ramonda spathulata) у Ramonda prunicia він на дорзальній поверхні голий і з боків перед заднім краєм $3 \quad 3-5$ рядами шипів. Середнє вістря ротоглоткового апарата у Ramonda spathulata зігнуте вентрально до вершини загострене, його довжина більша за довжину гіпостомального відділа. У Ramonda prunicia середне вістря 
розширене, ромбоподібне 3 випуклим вентральним краєм та кутоподібним виступом на дорзальному краї, його довжина менша за довжину середнього вістря.

VI тергіт постабдомена цілісний з довгими щетинками на задньому краї та дугоподібним виступом на передньому краї. VII тергіт цілісний 3 короткими щетинками на задньому краї та неглибоким впинанням по середині на передньому краї. VIII тергіт розділений на 2 дрібні склерити без щетинок. Кінцевий тергіт повністю редукований. VI стерніт на задньому краї $з$ щетинками по середині з голим проміжком. VII стерніт з рідкими щетинками на задньому краї та сенсорними ямками на задній половині. VIII стерніт багатокутної форми, майже повністю покритий сенсорними ямками (рис. 5: f).

У представників роду Periscepsia сперматеки грушеподібної форми, сильно пігментовані, без поперечних смужок, у яких вершинне округле впинання розміщене на вершині сперматек. Кожний канал сперматек у 4,0 рази довші, ніж капсули сперматек. Протоки сперматек впадають у вагіну кожна окремо. Придаткові залози тонкі і довші за сперматеки (рис.2: е).

Личинка 1-го віку невідома.

VI i VII тергіти цілісні на заднім краї 3 дрібними щетинками. VIII тергіт розділений на 2 дрібні склерити 3 щетинками на задньому краї. Кінцевий тергіт повністю редукований. Довжина VI стерніта рівна ширині, задня половина стерніта 3 дрібними щетинками. Довжина VII стерніта менша його ширини, його задній край 3 дрібними щетинками. VIII стерніт прямокутної форми 3 дрібними щетинками на задній його половині (рис. 5: g).

У представників роду Athricia капсули сперматек слабо пігментовані майже округлої форми без поперечних смужок, але їх вегетативний полюс прямий. Кожний канал сперматек у 6 разів довші за капсули сперматек. Протоки сперматек впадають у вагіну кожна окремо (рис. 2: g). Придаткові залози тонкі i довші за сперматеки.

Личинка 1-го віку невідома.

VI і VII тергіти цілісні на задньому краї 3 дрібними щетинками. VI тергіт на передньому краї по середині з дугоподібним виступом. VIII тергіт розділений на 2 дрібні склерити без щетинок. Кінцевий тергіт дорзально розділений на 2 склерити без щетинок. VI стерніт дугоподібної форми його задня половина 3 дрібними щетинками. VII стерніт багатокутної форми, його задній край з дрібними щетинками та сенсорними ямками. VIII стерніт майже квадратної форми i повністю покритий сенсорними ямками (рис. 5: h).

У представників роду Voria капсули сперматек слабо пігментовані майже округлої форми без поперечних смужок, але їх вегетативний полюс прямий. Кожний канал сперматек у 4 раз довші за капсули сперматек. Протоки сперматек впадають у вагіну кожна окремо (рис. 2: h). Придаткові залози тонкі i довші за сперматеки.

Личинка 1-го віку невідома.

VI i VII тергіти цілісні на заднім краї 3 щетинками різної довжини. VII тергіт по середині на передньому і задньому краях 3 неглибокими впинаннями. VIII тергіт розділений на 2 дрібні склерити без щетинок. Кінцевий тергіт повністю редукований. VI, VII, VIII стерніти на задньому краї з щетинками різної довжини. Довжина VII стерніта більша за довжину VI. Сенсорні ямки VIII стерніта розміщені лише на його вершині (рис. 5: i).

У представників роду Phyllomya сперматеки грушоподібної форми (рис.2: i), слабо пігментовані, 3 ледве помітними поперечними смужками. Кожний канал сперматек у 4 рази довший за капсули сперматек. Протоки сперматек впадають у вагіну кожна окремо. Придаткові залози тонкі і довші за сперматеки.

Псевдоцефал личинки 1-го віку 3 дрібними дископодібними сенсорними органами, їх ширина більша за висоту (Farynets 1976a). I-III грудні і I черевний сегменти голі. II-VII черевні сегменти на вентральній поверхні 3 групою густо розміщених і сильно пігментованих шипів. VIII сегмент голий. Дорзальна поверхня личинки гола, за виключенням II грудного сегмента. Задні дихальця розміщені на виростах заднього краю VIII черевного сегмента. Середнє вістря до вершини поступово звужується, зігнуте вентрально. Довжина середнього вістря майже в 2 рази більша за довжину гіпостомального відділу. Бокові склерити пігментовані, неправильної форми (рис. 4: d). 


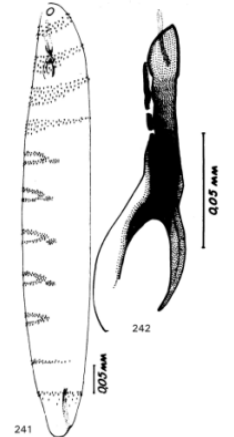

a

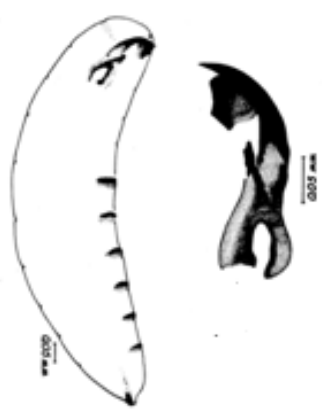

d

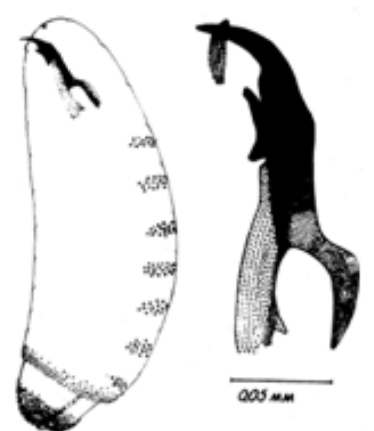

b

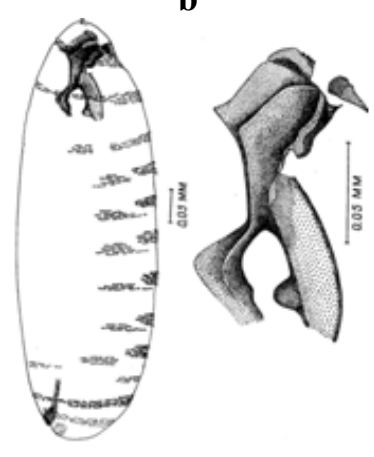

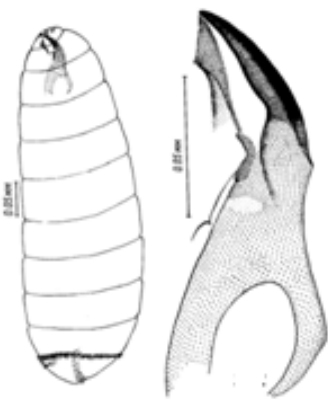

c

Рис. 4. Загальний вигляд личинок тахін 1-го віку: a - Eriothrix rufomaculatus (De Geer); b - Blepharomyia pagana (Meigen); c - Ramonda spathulata (Fallen); d - Phyllomya volvulus (Fabricius); e - Thelaira nigripes (Fabricius)

Fig. 4. General view of tachin's larvae of 1st age: a - Eriothrix rufomaculatus (De Geer); b - Blepharomyia pagana (Meigen); c - Ramonda spathulata (Fallen); d - Phyllomya volvulus (Fabricius); e - Thelaira nigripes (Fabricius)

VI, VII тергіти дорзально поділені на 2 однакові склерити 3 небагаточисельними дрібними щетинками на задньому краї. VII тергіт редукований з 2-4 щетинками на задньому краї. Склерити VIII тергіта дрібні без щетинок i з'єднані 3 VIII стернітом. Кінцевий тергіт повністю редукований. VI,VII стерніти на задньому краї 3 4-8 дрібними щетинками та сенсорними ямками. Задня половина VIII стерніта 3 сенсорними ямками, без щетинок (рис. 5: g).

У представників роду Thelaira капсули сперматек (рис. 2: ј) овальної форми, без поперечних смужок та прямим вегетативним полюсом. Кожний канал сперматек у 5,5 разів довші за капсули сперматек. Протоки сперматек зв'язані з вагіною однією короткою протокою (рис. 2: j). Придаткові залози тонкі.

Псевдоцефал личинки 1-го віку 3 одночленними папілоподібними антенами. I,II грудні сегменти на передньому краї з дрібними шипами: вентрально з більшою кількістю рядів шипів, ніж дорзально. III грудний сегмент дорзально голий, на вентральній поверхні 2 угрупування шипів. I-VII черевні сегменти дорзально голі, на вентральні поверхні 2 угрупування шипів. VIII черевний сегмент 3 двома смужками дрібних шипів: на передньому краї і по середині. Середнє вістря ротоглоткового апарата дорзально 3 гіпостомальним відділом утворює кутоподібний виступ. Довжина середнього вістря менша за довжину гіпостомального відділу. Бокові склерити видовжені мають різну форму (рис. 4: е).

VI тергіт дорзально розділений на 2 склерити 3 рідко розташованими, небагато чисельними щетинками на задньому краї. VII тергіт дорзально розділений, але повністю без помітних меж злитий з VII стернітом. VIII тергіт 3'єднаний 3 VIII стернітом. VI стерніт із звуженим переднім краєм, його задня половина 3 сенсорними ямками та щетинками на задньому краї. VII стерніт без щетинок, поверхня його 
задньої половини покрита лише сенсорними порами. VIII стерніт жолобоподібний до вершини звужений і виступає до самої вершини черевця, його поверхня з сенсорними порами (рис. 5: 1).

У представників роду Stomina капсули сперматек (рис.2: k) овальної форми, без поперечних смужок. Довжина каналів сперматек рівна довжині капсул сперматек. Протоки сперматек впадають у вагіну в складі загальної короткої протоки, яка з'єднує їх 3 вагіною (рис. 2: k). Придаткові залози тонкі і довші за сперматеки.

Псевдоцефал личинки 1-го віку 3 дископодібними медіально зближеними антенами та дрібними максилярними щупиками. Личинки I віку вкриті видовженими слабо пігментованими пластинками. На задньому кінці їх тіла довгі щетинки. Середнє вістря ротоглоткового апарата розширене.

VI i VII тергіти вузькі, цілісні у Stomina caliendrata на заднім краї з одним рядом дрібних щетинок. У Stomina tachinoides VII тергіт дорзально розділений на два склерити 3 одним рядом щетинок на задньому краї. VIII та кінцевий тергіти повністю редуковані. Ширина VI стерніта більша за його довжину, майже прямокутної форми. По краях стерніта декілька щетинок, по середині один ряд дрібних щетинок. VII стерніт за формою схожий на VI, але його задня половина поверхні покрита дрібними щетинками. VIII стерніт повністю редукований (рис. 5: 1, m).

Сукупність проаналізованих 22 морфологічних ознак сперматек і яйцекладів у 12 видів дає можливість скласти ключі для їх визначення.

\section{Таблиця для визначення видів}

1(12) Канали сперматек з'єднані з вагіною однією загальною короткою протокою (рис. 2: a, b, d, j, k) 2(7) Капсули сперматек з округлими впинаннями в екваторіальній площині (рис. 2: a, b).

3(4) VII тергіт цілісний, задній край якого 3 одним рядом щетинок та сенсорними порами (рис. 5: b)

Eriothrix prolixa (Meigen).

4(3) VII тергіт дорзально поділений на 2 латеральні склерити (рис. 5: a).

5(6) Задній край VII тергіта 3 щетинками

Eriotrix apenninus (Rondani).

6(5) Задній край VII тергіта без щетинок

Eriothrix rufomaculatus (DeGeer).

7(2) Капсули сперматек без округлих впинань в екваторіальній площині.

8(11) Канали сперматек у 3-5 разів довші за капсули сперматек. (рис. 2: d). VIII тергіт редукований.

9(10) VI тергіт цілісний з щетинками на задньому краї. VIII тергіт і стерніт без щетинок не злиті (рис. 5: е)

Peteina erinaceus (Fabricius). 10(9) VI тергіт дорзально поділений на 2 склерити 3 щетинками на задньому краї. VIII тергіт i склерит з'єднані, утворюючи суцільне кільце (рис. 2: j).

Thelaira nigripes (Fabricius). 11(8) Канали сперматек рівні з довжиною капсул сперматек. VIII тергіт і VIII стерніт повністю редуковані. VII тергіт цілісний (рис. 5: 1)

Stomina caliendrata (Rondani).
12(1) Канали сперматек з'єднані 3 вагіною кожний окремо.

13(22) VI тергіт цілісний 3 щетинками на задньому краї.

14(17) Канали сперматек у 6 разів довші за капсули сперматек. VIII стерніт без щетинок 3 сенсорними порами на всій поверхні (рис. 5: f, h). 15(16) VII тергіт на передньому краї по середині 3 неглибоким впинанням (рис. 5: f)

Ramonda spathulata (Fallén). 16(15) VII тергіт на передньому краї по середині без впинання (рис. 5: h)

Athrycia trepida (Meigen).

17(14) Канали та капсули сперматек інші за розмірами та формою.

18(21) Канали сперматек у 4,0-4,5 разів довші за капсули сперматек (рис.2: e, h).

19(20) VIII тергіт без щетинок (рис.5: i)

Voria ruralis (Fallen).

20(19) VIII тергіт 3 одним рядом щетинок на задньому краї

Periscepsia carbonaria Panzer. 21(18) Канали сперматек у 1,5-2,0 рази довші за капсули сперматек, які на вершині 3 папілоподібними виростами

Blepharomyia pagana (Meigen). 22(13) VI тергіт поділений на 2 склерити 3 невеликою кількістю щетинок на задньому краї. Капсули сперматек грушоподібної форми

Phyllomya volvulus (Fabricius). 

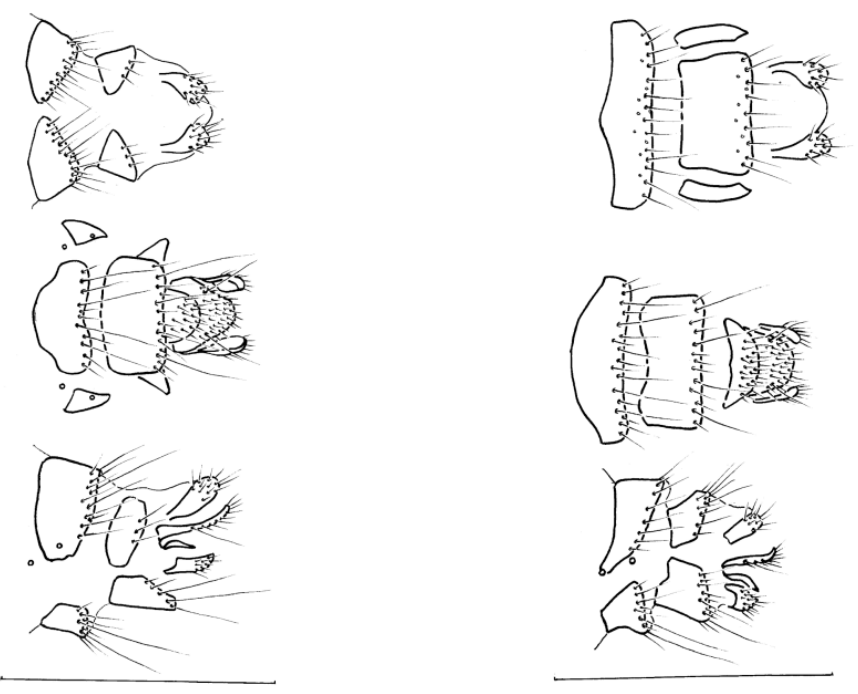

$\mathbf{a}$

b

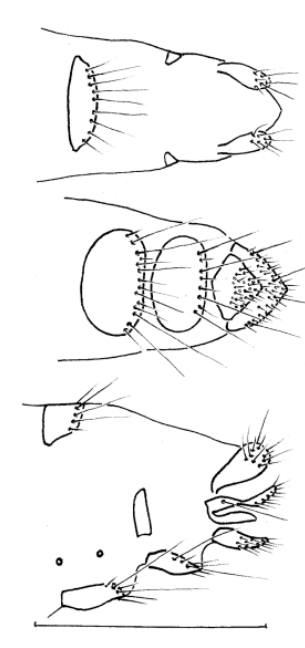

c
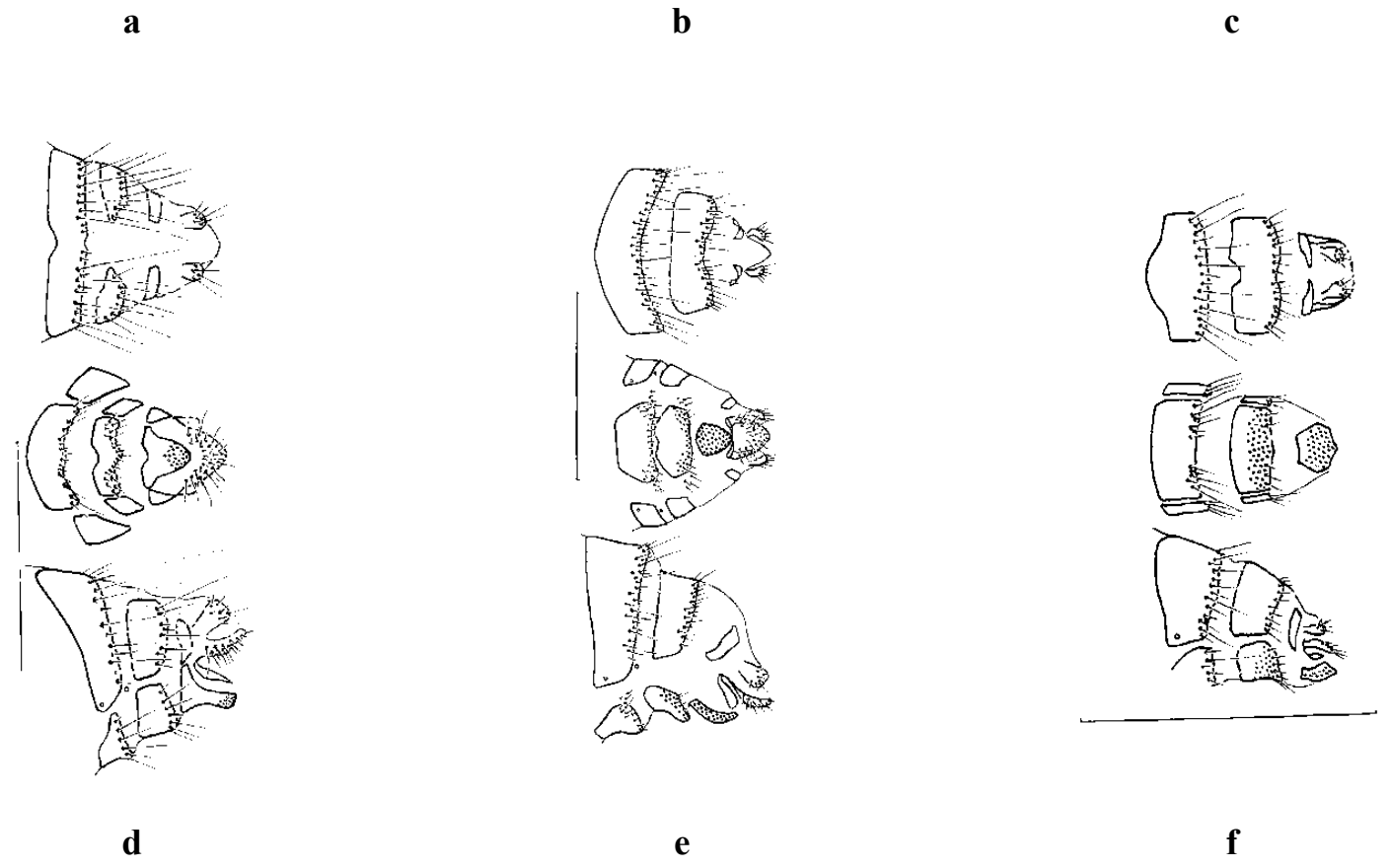

d

e 

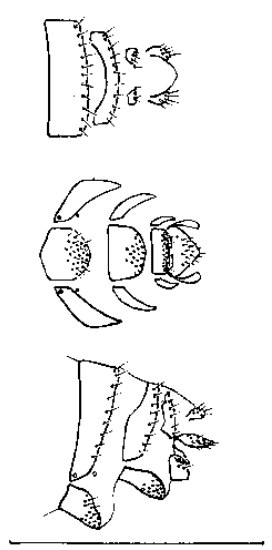

g

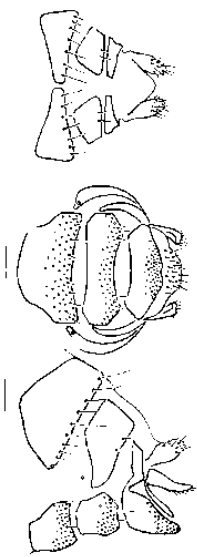

j
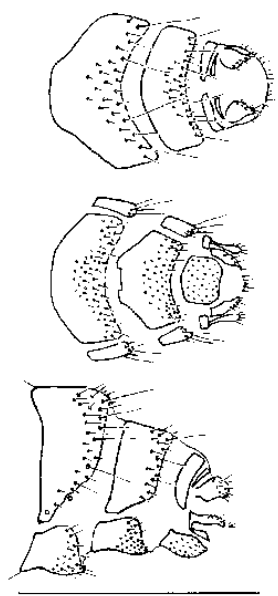

$\mathbf{h}$
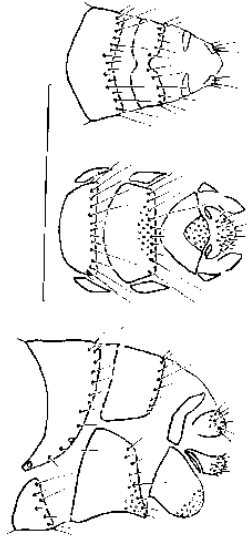

i

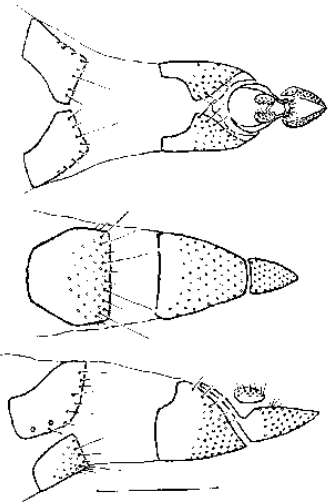

$\mathbf{k}$
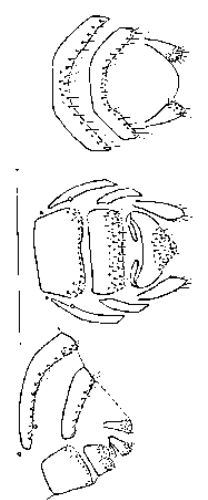

1

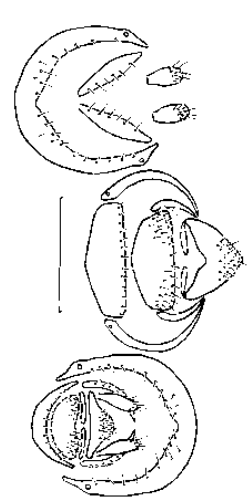

m

Рис. 5. Загальний план будови постабдомена самок тахін (зверху вниз: вигляд зверху, вигляд знизу, вигляд збоку): a - Eriothrix apenninus (Rondani); b - Eriothrix prolixa (Meigen); c - Eriothrix rufomaculatus (De Geer); d - Blepharomyia pagana (Meigen); e - Peteina erinaceius (Fabricius); f - Ramonda spathulata (Fallen); g - Periscepsia carbonaria (Panzer); h - Athrycia trepida (Meigen); i - Voria ruralis (Fallen); $\mathrm{j}$ Phyllomya volvulus (Fabricius); $\mathrm{k}$ - Thelaira nigripes (Fabricius); 1 - Stomina caliendrata (Rondani); $\mathrm{m}$ Stomina tachinoides (Fallen)

Fig. 5. General scheme of tachin's females postabdomen structure (from up to down: top view, bottom view, lateral view): a - Eriothrix apenninus (Rondani); b - Eriothrix prolixa (Meigen); c - Eriothrix rufomaculatus (De Geer); d - Blepharomyia pagana (Meigen); e - Peteina erinaceius (Fabricius); $\mathrm{f}$ - Ramonda spathulata (Fallen); g - Periscepsia carbonaria (Panzer); h - Athrycia trepida (Meigen); i - Voria ruralis (Fallen); $\mathrm{j}$ Phyllomya volvulus (Fabricius); $\mathrm{k}$ - Thelaira nigripes (Fabricius); 1 - Stomina caliendrata (Rondani); $\mathrm{m}$ Stomina tachinoides (Fallen)

Вивчені зміни генітальних структур самок Voriini мають неповний характер через те, що їх аналіз здійснюється на неповному матеріалі, який охоплює невелику кількість видів 310 родів. Результати дослідження проаналізовані у формі бінарних матриць і дендрограм (рис. 6). Одержані 
показники 18 бінарних ознак постабдомена, сперматек та личинок 1-го віку дозволяють більш аргументовано трактувати диференціацію таксонів родового рівня та філогенію.

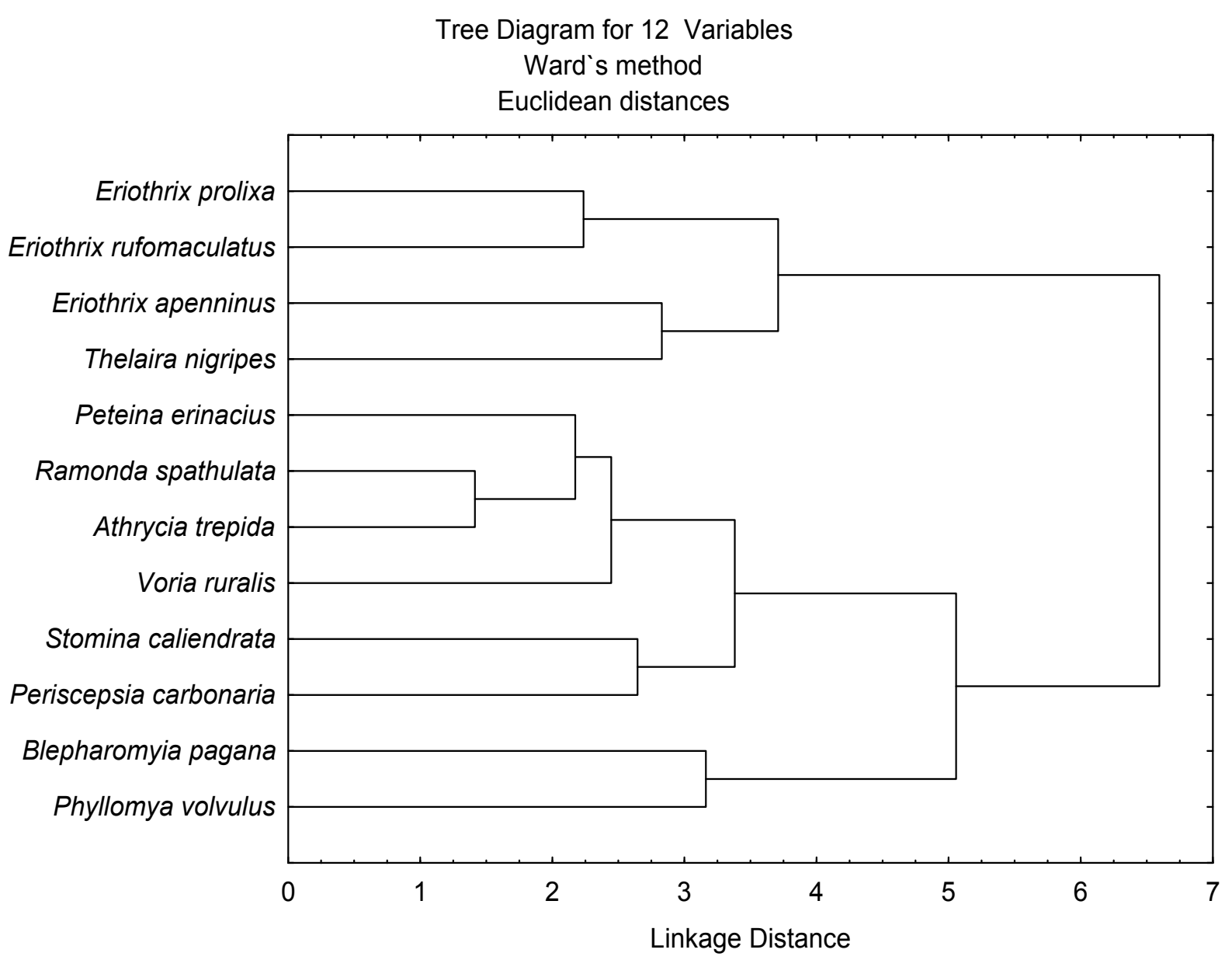

Рис. 6. Спорідненість представників триби Voriini за порівняльно-морфологічним аналізом постабдомена, сперматек та личинок 1-го віку

Fig. 6. Relationship of the Voriini tribe by comparative morphological analysis of the postbdomen, spermathecae, and first age larvae

За особливостями, структури геніталій самок Voriini виявились досить різноманітними. 3 одного боку Voriini подібні за окремими структурами геніталій 3 Dexiini: зокрема повна редукція кінцевого тергіта, редукція VIII та збереження у більшості цілих VI, VII, іноді VIII тергітів, редукція волосків на поверхні VIII стерніта і виникнення на ньому сенсорних пор. Також у деяких представників Voriini (Eriothrix, Peteina, Thelaira, Stomina) канали сперматек подібно до Dexiini з'єднані 3 вагіною одним загальним коротким протоком. Серед цього угруповання виділяються Eriothrix будовою капсул сперматек та Stomina повною редукцією VIII, кінцевого тергітів і VIII стерніта.

\section{Висновки}

На наш погляд, зв'язок каналів сперматек 3 вагіною не зазнає адаптивних змін і відображає зв'язки таксонів високого рангу.

Таким чином, морфологічні особливості генітальних структур самок, личинки 1-го віку 
правомірно використовувати поряд 3 морфологічними ознаками імаго при з'ясуванні родинних відносин, видових і родових відмінностей, а також при вивченні філогенії.
BELANOVSKIY, I.D. (1951) Takhiny Ukrainskoj SSR. AN USSR, Kiev (in Russian).

FARYNETS, S.I. (1976a) Lichinki I stadia muh-takhin (Diptera, Tachinidae) Zakarpat'ja. Entomologicheskoje obozrenije, 55(2): 458-466 (in Russian).

FARYNETS, S.I. (1976b) Lichinki I stadia takhin (Diptera, Tachinidae) - parazitov lichinok Zhukovlistojedov. Zoologicheskij zhurnal, 55(6): 944-947 (in Russian).

FARYNETS, S.I. (1976c) K faune takhin (Diptera, Tachinidae) Zakarpat'ja. Soobschenije 1. Podsemejstva Exoristinae, Phasiinae. Vestnik zoologii, 3: 66-70 (in Russian).

FARYNETS, S.I. (1976d) K faune takhin (Diptera, Tachinidae) Zakarpat'ja. Soobschenije 2. Podsemejstva Tachininae, Dexiinae. Vestnik zoologii, 3:74-76 (in Russian).

FARYNETS, S.I. (1996) Morfologia jajtseklada takhin nekotoryh rodov triby Exorisrini (Diptera, Tachinidae). Vestnik zoologii, 1-2:79-84 (in Russian).

FARYNETS, S.I. (1997) Morfologia yaitsekladiv deiakyh vydiv takhin (Diptera, Tachinidae), yaki vidkladaiut yaitsia pid nadkryla zhukiv. Naukovyi visnyk UzhDU. Seria Biologia, 4: 167-170 (in Ukrainian).

FARYNETS, S.I. (2000) Takhiny (Diptera, Tachinidae) Ukrainskyh Karpat. Naukovyi visnyk UzhDU. Seria Biologia, 8: 97-103 (in Ukrainian).

FARYNETS, S.I. (2002) Morfologichni osoblyvosti postabdomena samok tryby Phasiini (Diptera, Tachinidae). Naukovi zapysky Derzhavnoho pryrodoznavchoho muzeiu, 17: 111-116 (in Ukrainian).

FARYNETS, S.I. (2003) Morfologichni osoblyvosti spermatek I prydatkovyh zaloz samok takhin tryby Goniini (Diptera, Tachinidae). Naukovyi visnyk UzhNU. Seria Biologia, 12: 145-150 (in Ukrainian).

FARYNETS, S.I. (2008) Morfologichni osoblyvosti henitalii samok deiakyh tryb pidrodyny Tachininae (Diptera, Tachinidae). Naukovyi visnyk UzhNU. Seria Biologia, 23: 237-242 (in Ukrainian).

HERTING,B. (1957) Das weibliche Postabdomender Caliptraten Fliegen (Diptera) undsien Merkmalswertfur Systematic der Gruppe. Zeitschrift für Morphologie und Ökologie der Tiere, 45: 429-561.

HERTING, B. (1960) Biologie der Westpaläarktischen Raupenfliegen (Dipt., Tachinidae). Monographien zur Angewandten Entomologie, 16. Verlag Parey, Hamburg-Berlin.

HERTING, B. (1984) Catalogue of Palaearctic Tachinidae (Diptera). Stuttgarter Beiträge zur Naturkunde. Serie A (Biologie), 369: 1-228.
HORI, K. (1961) Comperative Anatomy of the Internal Organs of the Calyptrate Muscoid Flies. II. Female Internal Sexuel Organs of the Adult Flies. The Sciences Reports of the Kanazawa University, 7(2): 61-101.

KHITSOVA, L.N., CHERNENKO, YU.I., ISAEVA, G.A. (1977) K poznaniju biologii takhiny Dinera grisescens F11. (Diptera, Tachinidae) v uslovijah Voronezhskogo zapovednika. In: Okhrana prirody Tsentral'noChernozemnoj polosy. Voronezh, vyp.8: 112-114 (in Russian).

KULIKOVA, N.A. (1984) Sravnitel'no-morfologicheskij analiz strojenia postabdomena samok muh semejstva Sarcophagidae.Voprosy evoljutsii I filogenii dvukrylyh. Trudy MOIP: 21-30 (in Russian).

LOBANOV, A.M. (1977) Morfologia jajtseklada i sistematika muh sem. Muscidae. Sistematika I evoljutsia dvukrylyh nasekomyh. Trudy AN SSSR: 5764 (in Russian).

RIKHTER, V.A., FARINETS, S.I. (1979a) Lichinki I vozrasta takhin dvuh vidov roda Dinera R.-D. (Diptera, Tachinidae). Trudy Zooligicheskogo institute AN SSSR, 82: 113-117 (in Russian).

RIKHTER, V.A., FARINETS, S.I. (1979b) LichinkiI vozrastatakhinrodaTrichoparia (Diptera, Tachinidae).TrudyZooligicheskogoinstituteANSSSR, 83: 133-137 (inRussian).

RIKHTER, V.A., FARINETS, S.I. (1983) Lichinki I vozrasta takhin podsem. Dexiinae (Diptera, Tachinidae) fauny SSSR. Entomologicheskoje obozrenije, 62(4): 811-834 (in Russian).

RIKHTER, V.A., FARINETS, S.I. (1986) Lichinki I vozrasta takhin trib Angiorhinini i Palpostomini (Diptera, Tachinidae) fauny SSSR. Entomologicheskoje obozrenije, 65(1): 195-201 (in Russian).

RIKHTER, V.A., FARINETS, S.I. (1989) Opisanije lichinok I vozrasta takhin podsemeistva Tachininae i Voriinae (Diptera, Tachinidae). Entomologicheskoje obozrenije, 68(4): 850-864 (in Russian).

RODENDORF, B.B. (1937) Semejstvo Sarcophagidae. In: Fauna SSSR. Nasekomyje dvukrylyje. AN SSSR, Moskva (in Russian).

TACHI, T., SHIMA, H. (2000) Taxonomic study of the genus Ceromya Robineau-Desvoidy of Japan (Diptera: Tachinidae). Beiträge zur Entomologie, Berlin, 40: 129-150.

THOMPSON, W.R. (1923) Recherchessur les Diptéres Parasites. Les larvesprimaires des Tachinidae du groups des Echinomyiinae. Annales des épiphyties et de phytogénétique, 9: 137-201. 
THOMPSON, W.R. (1924) Les larves primaires des Tachinaires aoeufa microtypes. Annales de Parasitologie Humaine et Comparee, 3-4: 185-201; 279-306.

THOMPSON, W.R. (1926) Recherchersur les larves des Tachinaires Sturmia, Winthemia, Carcelia et Exorista. Annales de Parasitologie Humaine et Comparee, 4: 111-125; 207-227.
TSCHORSNIG, H.-P., HERTING, B. (1994) Die Raupenfliegen (Diptera: Tachinidae) Mitteleuropas: Bestimmungstabellen und Angabenzur Verbreitung und Okologie der einzelnen Arten. Stuttgarter Beitragezur Naturkunde.-Serie A (Biologie), 506: 170.

VIKTOROV, G.A. (1967) Problemy dinamiki chislennosti nasekomyh naprimere vrednoj cherepashki. Nauka, Moskva (in Russian). 